\title{
Analysis of Education and Family Support Factor on Compliance with Taking Anti Tuberculosis Drugs (OAT) in Pulmonary Tuberculosis (TB) Patients in Tebing Tinggi City
}

\author{
Evi Novalita Tarigan ${ }^{1}$, Rahayu Lubis $^{2}$, Erna Mutiara ${ }^{3}$ \\ ${ }^{1,2,3}$ Universitas Sumatera Utara, Indonesia \\ Corresponding Author: Evi Novalita Tarigan
}

\section{ABSTRACT}

Indonesia ranks second in the world as a country that has the number of tuberculosis sufferers after India. Although directly observed shortcourse treatment (DOTS) recommended by the World Health Organization (WHO) has proven to be very effective in the treatment of tuberculosis, patient compliance with anti tuberculosis drugs (OAT) is a major obstacle in controlling tuberculosis. The purpose of this study was to analyze of education and family support factors in compliance with taking anti tuberculosis drugs (OAT) in Pulmonary Tuberculosis (TB) Patients in Tebing Tinggi City. The populations in this study were all tuberculosis patients in Tebing Tinggi City from January to December 2020. A sample of 78 people was obtained using purposive sampling technique. This study uses multivariate analysis with multiple Poisson regression test. The results of multivariate analysis with multiple Poisson regression $(\mathrm{p}<0.05)$ showed that education ( $\mathrm{p}=0.043$; $\mathrm{PR}=1.539,95 \% \mathrm{CI} 1.013$ 2.338) was associated with compliance with taking OAT in Tebing Tinggi City. Family support $(\mathrm{p}=0.008 ; \mathrm{PR}=1.737$, 95\%CI 1.158 2.604) was associated with compliance with taking OAT in Tebing Tinggi City. It is hoped that TB patients can increase their knowledge by attending counseling, counseling and home visits, following the rules of taking OAT and immediately consulting with officers if they experience side effects of OAT. It is expected that families can provide motivation, seek information, accompany taking OAT, provide transportation for control to the community
\end{abstract}

health center (Puskesmas), and facilitate patients with an android-based OAT drinking calendar application.

Keywords: Education, Family Support, Compliance with Taking Anti Tuberculosis Drugs (OAT)

\section{INTRODUCTION}

Tuberculosis is one of the ten leading causes of death in the world, and the leading cause of death caused by infectious diseases. The problem of TB in the world is getting worse with the emergence of the HIV/AIDS pandemic, TB-RO and the incidence of Covid-19. It is estimated that the Covid-19 pandemic could cause an additional 6.3 million TB cases globally from 2020 to 2025 and an increase in mortality by 1.4 million TB deaths (World Health Organization, 2020).

According to the World Health Organization (2020) report, it is estimated that there will be around 10 million new cases of tuberculosis sufferers in the world in 2019. It is estimated that the number of deaths from TB disease among HIV negative people is 1.2 million people and the number of deaths due to TB disease among HIV positive people is 208,000 people.

Indonesia ranks second in the world as a country that has the number of tuberculosis sufferers after India. Based on a report from the Kementerian Kesehatan 
(2020) the number of TB cases found in Indonesia (case detection rate tuberculosis/CDR) in 2019 decreased when compared to 2018 where in 2018 the discovery of TB cases was 67.2 percent (566,623 cases) of all cases. New TB cases were estimated $(843,000$ cases $)$ while in 2019 only 64.5 percent $(543,874$ cases $)$ of all new TB cases were estimated $(843,000$ cases) but when compared to 2017 the discovery of TB cases was only 42.8 percent (425,089/992,441 cases). Although the number of TB cases found is relatively increasing, the $\mathrm{TB}$ case finding rate (CDR) in Indonesia is still far below the standard recommended by $\mathrm{WHO}$, which is greater than 90 percent. By province, in 2019 only West Java (96.2\%) and Gorontalo (94.6\%) had reached CDR figures above 90 percent (in 1st and 2nd positions), while North Sumatra was only 47.7 percent (in the 14th position) (Kementerian Kesehatan, 2020).

Globally, efforts made to reduce the incidence of tuberculosis in 2000-2018 have shown a decline of 1.6 percent per year and a decrease of 2 percent between 2017 and 2018. Cumulatively, the decline in the incidence of tuberculosis between 2015 and 2018 was only 6.3 percent. However, this number is still far from the target that must be achieved between 2015 and 2020 in the strategy to end tuberculosis (END TB), which is 20 percent. The number of deaths from tuberculosis between 2015 and 2018 decreased by 11 percent. This amount only reaches a third of the 35 percent target to be achieved by 2020 (World Health Organization, 2019).

Although directly observed shortcourse treatment (DOTS) recommended by the World Health Organization (WHO) has proven to be very effective in the treatment of tuberculosis, patient compliance with anti tuberculosis drugs (OAT) is a major obstacle in controlling tuberculosis.

Tebing Tinggi City is part of North Sumatra Province which has a high number of tuberculosis sufferers. In 2016 the coverage of TB case finding was 20.76 percent (211 cases) of all estimated new TB cases (1,016 cases), in 2017 it was 20.96 percent (217 cases) of all estimated new TB cases $(1,035)$, in 2018 it was 28.50 percent (291 cases) of all estimated new TB cases $(1,021)$, in 2019 it was 24.84 percent $(238$ cases) of all estimated new TB cases (958 cases) and in 2020 it was 21, 54 percent (215) of all estimated new TB cases (998 cases) (Dinas Kesehatan Tebing Tinggi, 2020).

Based on research conducted by several researchers, there are several factors that support the obedient attitude of TB patients taking anti-tuberculosis (OAT) drugs, namely research by Dhewi, Armiyati and Supriyono (2012) which states that knowledge, patient attitudes and family support are factors related to drinking compliance. According to Wulandari (2018) research at the Rumah Sehat Terpadu Hospital, the factors related to adherence to medication for TB patients are the patient's perception of the disease, the attitude of the health worker, the perception of distance to the hospital, the role of the supervisor taking medication and the side effects of the drug. Budianto (2015) states that age and education are factors related to medication adherence.

The purpose of this study was to analyze of education and family support factors in compliance with taking anti tuberculosis drugs (OAT) in Pulmonary Tuberculosis (TB) Patients in Tebing Tinggi City.

\section{RESEARCH METHODS}

The research design is cross sectional study. According to Ghazali et al in Sastroasmoro and Ismael (2014), the measurement of variables in cross-sectional design research is not limited to being precise at the same time but has the meaning that each subject is subjected to one measurement without any follow-up or repetition of measurements (Sastroasmoro and Ismael, 2014)

This research was conducted in nine (9) Puskesmas which are technical implementing units (UPT) of the Tebing 
Tinggi City Health Office. The nine health centers are Pabatu Health Center, Pasar Gambir Health Center, Satria Health Center, Rantau Laban Health Center, Sri Padang Health Center, Teluk Karang Health Center, Rambung Health Center, Brohol Health Center and Tanjung Marulak Health Center. The time of this research was carried out from July 2020 to May 2021.

The population in this study were all tuberculosis patients in Tebing Tinggi City from January to December 2020. A sample of 78 people was obtained using purposive sampling technique. This study uses multivariate analysis with multiple poisson regression test.

The dependent variable is the variable that is influenced or which is the result of the independent variable (Murti, 2016). The dependent variable in this study was adherence to taking anti-tuberculosis drugs (OAT). The independent variable is the variable that influences or causes the change or emergence of the dependent variable (Riyanto, 2011). The independent variables in this study were education and family support.

This study uses multivariate analysis with multiple Poisson regression test. a) Selecting independent variables to be included in the multivariate analysis, namely those variables which in bivariate analysis have a $p$ value of less than 0.25 or variables that are theoretically important, included in the multivariate analysis process, b) gradually independent variables are selected one by one in stages to be excluded from the model, the first to be excluded is the independent variable that has the largest $p$ value in bivariate analysis until all independent variables that have a $p$ value greater than 0.05 are removed from the model so that a fit model is found.

\section{RESULT}

\section{Description of Research Site}

Tebing Tinggi City is one of the cities in North Sumatra Province which is approximately $80 \mathrm{Km}$ from Medan City and is located on the main road of Sumatra, which connects the East Cross and Central Sumatra Cross through a diagonal cross on the Tebing Tinggi, Pematang Siantar, Parapat roads., Balige and Siborong-borong. The city of Tebing Tinggi consists of 5 subdistricts and 35 urban villages with an area of $38,438 \mathrm{~km} 2$ and a population of around 164,323 people (2019) with a population density of 5,623 people/km2 with a regional topography, generally flat and undulating with an altitude above sea level between 18 to 34 meters with an average annual rainfall of 1,776 milli meters per year with an air humidity of 80 percent to 90 percent.

Geographically, Tebing Tinggi City is located in Tebing Tinggi City, which is located at the geographical coordinates of $03^{\circ} 19^{\prime} 00^{\prime \prime}$ North Latitude - 03' 21" 00" North Latitude and 98 11' East Longitude $98^{\circ} 21^{\prime}$ East Longitude, an altitude of 26-34 meters above sea level and has a the topography is flat to undulating. Tebing Tinggi City has an average air temperature of $25 \mathrm{oC}-27 \mathrm{oC}$. Regional Limits as follows:

a. To the north it is bordered by PTPN III Kebun Rambutan, Serdang Bedagai Regency.

b. East side borders with PT. Socfindo Clean Soil Gardens, Serdang Bedagai Regency.

c. On the south side, it is bordered by PTPN III Kebun Pabatu, Serdang Bedagai Regency.

d. On the west side, it is bordered by PTPN III Kebun Bandar Bejambu, Serdang Bedagai Regency.

Tebing Tinggi City is traversed by several large rivers and small rivers which generally have water currents towards the North and Northeast and empties into the Malacca Strait. The city is crossed by the Padang River which is the main river with a length of about $\pm 16.22 \mathrm{~km}$ and a width of \pm 65 meters. Other major rivers are the Bailang River, the Valley River, and the Sibarau River. Small rivers in the City area are the Segiling River and the Sibangauan River. 


\section{Population}

The population of Tebing Tinggi City in 2019 is based on data from the Central Statistics Agency (BPS) of Tebing Tinggi City as many as 164,402 people, with details, with details of 81,281 male residents and 83,121 female residents. The population of Tebing Tinggi City is mostly found in Batipe District by 23.06 percent (37.909 people) and Rambutan District by 22.14 percent $(36,392$ people) while the most densely populated area is Tebing Tinggi Kota District by 15.48 percent $(7,328$ people).

The population by age group in Tebing Tinggi City in 2019 was dominated by the age group of 25 years to 44 years as many as 47,410 people and the age group 45 years and over as many as 43,316 people while the livelihoods of the population as much as 71.10 percent $(51,594$ people) were engaged in the service sector, namely trade, transportation, finance and social services.

\section{Description of Characteristics of Patients with Pulmonary TB}

This study was conducted in February-April 2021, the minimum number of samples in this study was collected as many as 78 pulmonary TB patients who were in the advanced stage of treatment. Pulmonary TB patients collected were TB patients registered in the TB treatment register from July to December 2020 at nine health centers in Tebing Tinggi City. The number of respondents who were interviewed in each area of the puskesmas can be seen in Table 1 .

Table 1. Number of Pulmonary TB Patients in Each Puskesmas in Tebing Tinggi City

\begin{tabular}{|r|l|c|c|}
\hline No & Puskesmas & $\begin{array}{c}\text { Pulmonary TB } \\
\text { Patients }\end{array}$ & Percentage \\
\hline 1 & Puskesmas Pabatu & 9 & 11.54 \\
\hline 2 & $\begin{array}{l}\text { Puskesmas Teluk } \\
\text { Karang }\end{array}$ & 7 & 8.97 \\
\hline 3 & Puskesmas Satria & 10 & 12.82 \\
\hline 4 & $\begin{array}{l}\text { Puskesmas Pasar } \\
\text { Gambir }\end{array}$ & 12 & 15.38 \\
\hline 5 & $\begin{array}{l}\text { Puskesmas Rantau } \\
\text { Laban }\end{array}$ & 7 & 8.97 \\
\hline 6 & Puskesmas Rambung & 9 & 11.54 \\
\hline 7 & Puskesmas Berohol & 8 & 10.26 \\
\hline 8 & $\begin{array}{l}\text { Puskesmas Sri } \\
\text { Padang }\end{array}$ & 9 & 8.97 \\
\hline 9 & $\begin{array}{l}\text { Puskesmas Tanjung } \\
\text { Marulak }\end{array}$ & 7 & 100.00 \\
\hline & \multicolumn{2}{|c|}{ Source: Puskesmas in Tebing Tinggi City } \\
\hline
\end{tabular}

\section{Multivariate Analysis}

Multivariate analysis was conducted to see the independent variables that were most related to adherence to taking OAT in pulmonary TB patients. The statistical test used is the multiple Poisson regression test using the backward method. The independent variables that are included in the multivariate analysis are the variables which in the bivariate analysis have a $\mathrm{p}$ value of 0.25 . Variables that have been entered into the model are selected one by one starting from the variable that has the largest $p$ value until the model that is most related to OAT adherence is found. The initial and final models of multivariate analysis can be seen in Table 2 as follows.

Table 2. Result of Multivariate Analysis of Related Factors with Compliance with Taking Anti Tuberculosis Drugs (OAT)

\begin{tabular}{|c|c|c|c|c|c|c|}
\hline \multirow[t]{2}{*}{ Variable } & \multicolumn{3}{|c|}{ Early Model } & \multicolumn{3}{|c|}{ Final Model } \\
\hline & PR & $95 \%$ CI PR & Pvalue & PR & 95\% CI PR & Pvalue \\
\hline \multicolumn{7}{|l|}{ Education } \\
\hline High & 1.448 & $0.939-2.232$ & 0.094 & 1.539 & $1.013-2.338$ & 0.043 \\
\hline Low & ref & & & & & \\
\hline \multicolumn{7}{|l|}{ Family Support } \\
\hline Good & 1.514 & $0.989-2.316$ & 0.056 & 1.737 & $1.158-2.604$ & 0.008 \\
\hline Not good & ref & & & & & \\
\hline
\end{tabular}

The results of multivariate analysis with multiple poisson regression $(\mathrm{p}<0.05)$ showed that education $(\mathrm{p}=0.043 ; \mathrm{PR}=1.539$, 95\% CI 1.013-2.338) was associated with compliance with taking OAT in Tebing
Tinggi City. Family support $\quad(\mathrm{p}=0.008$; $\mathrm{PR}=1.737, \quad 95 \% \mathrm{CI} \quad 1.158-2.604) \quad$ was associated with compliance with taking OAT in Tebing Tinggi City. 


\section{CONCLUSION AND SUGGESTION}

The results of multivariate analysis with multiple poisson regression $(\mathrm{p}<0.05)$ showed that education $(\mathrm{p}=0.043 ; \mathrm{PR}=1.539$, 95\% CI 1.013-2.338) was associated with compliance with taking OAT in Tebing Tinggi City. Family support $(\mathrm{p}=0.008$; $\mathrm{PR}=1.737, \quad 95 \% \mathrm{CI} \quad 1.158-2.604) \quad$ was associated with compliance with taking OAT in Tebing Tinggi City.

It is hoped that TB patients can increase their knowledge by attending counseling, counseling and home visits, following the rules of taking OAT and immediately consulting with officers if they experience side effects of OAT. It is expected that families can provide motivation, seek information, accompany taking OAT, provide transportation for control to the community health center (Puskesmas), and facilitate patients with an android-based OAT drinking calendar application.

\section{Acknowledgement: None}

\section{Conflict of Interest: None}

\section{Source of Funding: None}

\section{Ethical Approval: Approved}

\section{REFERENCES}

1. Budianto, A. (2015). Usia dan Pendidikan Berhubungan dengan Perilaku Kepatuhan Minum Obat Pada Penderita Tb Paru. Ilmiah Kesehatan, 4(8).

2. Dhewi, G. I., Armiyati, Y., \& Supriyono, M. (2012). Hubungan Antara Pengetahuan, Sikap Pasien dan Dukungan Keluarga dengan Kepatuhan Minum Obat pada Pasien
TB Paru di BKPM Pati. Karya Ilmiah STIKES Muhammadiyah Semarang. Accessed from http://ejournal.stikestelogorejo.ac.id.

3. Dinas Kesehatan Tebing Tinggi. (2020). Register TB Kota Tebing Tinggi. Tebing Tinggi.

4. Kementerian Kesehatan. (2020). Profil Kesehatan Indonesia Tahun 2019. Jakarta: Kementerian Kesehatan RI.

5. Murti, B. (2016). Prinsip dan Metode Riset Epidemiologi. Karanganyar Jawa Tengah: Bintang Fajar Offset.

6. Riyanto. (2011). Aplikasi Metodologi Penelitian Kesehatan. Yogyakarta: Nuha Medika.

7. Sastroasmoro, S., \& Ismael, S. (Ed). (2014). Dasar-Dasar Penelitian Klinis. Edisi Kelima. Jakarta: CV. Sagung Seto.

8. Wulandari, D. H. (2018). Analisis Faktorfaktor yang Berhubungan dengan Kepatuhan Pasien Tuberkulosis Paru Tahap Lanjutan Untuk Minum Obat di RS Rumah Sehat Terpadu Tahun 2015. Journal Administrasi Rumah Sakit Indonesia, 2(1), 17-28.

9. World Health Organization. (2019). Global Tuberculosis Report. Geneva: World Health Organization. Lincensi: CC BY-NC-SA 3.0 IGO.

10. World Health Organization. (2020). Global Tuberculosis Report. Geneva: World Health Organization. Licence: CC BY-NC-SA 3.0 IGO.

How to cite this article: Tarigan EN, Lubis R, Mutiara E. Analysis of education and family support factor on compliance with taking anti tuberculosis drugs (OAT) in pulmonary tuberculosis (TB) patients in Tebing Tinggi City. International Journal of Science \& Healthcare Research. 2021; 6(2): 351-355. DOI: https://doi.org/10.52403/ijshr.20210461 